Furlani M., 1990 - Avifauna del Monte Conero. Risultati di un primo anno di ricerca - Provincia di Ancona Assessorato Caccia e Pesca, Ancona.

Giacchini P. (a cura di), 2007 - Atlante degli uccelli nidificanti della provincia di Ancona - Provincia di Ancona IX Settore Tutela dell'Ambiente-Area Flora e Fauna, Ancona.

Pandolfi M. \& Frugis S., 1987 - Check-list degli Uccelli delle Marche - Riv. ital. Orn., 57 (3-4): 221-237.

Villani V. \& Furlani M. (a cura di), 2006 - L'oasi di San Gaudenzio di Senigallia. Valori storici ed ambientali - Gruppo "Società e Ambiente", Senigallia.

Mauro Mencarelli $^{1}$, Niki Morganti ${ }^{2} \&$ Francesca Morici $^{3}$

${ }^{1}$ Via XXVIII Settembre, 28 - I-Senigallia (AN)

${ }^{2}$ Strada della Mandriola, 128/a - I-Senigallia (AN)

${ }^{3}$ Via Vico, 3 - I-Senigallia (AN)

\title{
EVALUATION OF AN AERIAL SCARING DEVICE FOR BIRDS DAMAGE PREVENTION TO AGRICULTURAL CROPS
}

\begin{abstract}
RIASSUNTO - Valutazione di un sistema aereo di disturbo degli uccelli per prevenire i danni da loro provocati ai raccolti agricoli.

Vengono usati molti strumenti visivi per spaventare gli uccelli che danneggiano i raccolti agricoli. Molti di essi sono efficaci solo per brevi periodi e in piccole aree, dato che dopo pochi giorni gli uccelli in genere vi si abituano, a causa dell'immobilità di questo tipo di sistema. Per questa ragione abbiamo sperimentato la combinazione di uno speciale aquilone e di un pallone Mylar, riempito di elio, monouso, "Helikite ${ }^{\circledR ”}$, per spaventare gli uccelli. Due prove vennero effettuate in campi di mais in germoglio (su cornacchie grigie, Corvus corone cornix) e in campi di girasoli in maturazione (su colombacci, Columba palumbus e tortore, Streptopelia turtur e S. decaocto). I risultati hanno mostrato che Helikite può costituire un efficace strumento per ridurre i danni provocati da colombacci e tortore nei riguardi dei girasoli in maturazione $(1,16 \%$ di capolini danneggiati nei transetti vicino all'Helikite, contro il 13,25\% di capolini danneggiati nei transetti lontani dall'Helikite; $\mathrm{P}<0,0001)$ e per ridurre il danno delle cornacchie nei campi di mais in germoglio (19,1\% di piante danneggiate nel lotto di controllo, contro $4,2 \%$ di piante danneggiate nel lotto con Helikite; $\mathrm{P}<0,0001)$.
\end{abstract}

\section{Introduction}

Many kinds of agricultural crops can be damaged by bird species. Visual devices as eye spotted balloons and flashing tapes have became quite popular in the last few years (CoNOver, 2002; GorReri \& MoscARdini, 1997). Most of them are effective only for short periods and in small areas, since habituation generally occurs after a few days, due to the immobility of this kind of systems.

A promising visual tool is Alsopp Helikite ${ }^{\circledR}$. It is a $0.9-\mathrm{m}$ diameter heliumfilled balloon with a kite and stabilizer attached that allows flights in high winds. (SANTILLI et alii, 2004; SEAMAN et alii, 2002). 
For these reasons our purpose was to conduct field evaluations of the Helikite efficacy in areas with sprouting corn and ripening sunflowers. Our null hypothesis was that damages would not decrease in response to the device.

\section{Data and Methods}

Sprouting corn: We virtually divided the experimental field in 2 plots of 13 ha each, with a transition strip of 3.5-ha between the two plots ( 80 -m large). Four Helikites were installed in one plot 3 days after seeding. The other plot was used as control. After 2 weeks from seeding, the damages by birds were evaluated in the two fields. We casually selected transects of $10-\mathrm{m}$ along the rows (67 in the control plot and 57 in the Helikite plot). The seeds damaged or disappeared because eaten by the birds, and the undamaged seeds and plants were counted. Great attention was paid to select transects in all parts of the plots (center and edges). Ripening sunflower: One Helikite was installed in a field on a bean-pole (2-m high) with a maximum height above the ground of $30-\mathrm{m}$ and the adjacent field (bordering along the short side) was used as control. Four crossing transects were selected for each field. Every week the damage by birds along each transect was evaluated. The observer casually selected about 40 plants closest to the transects to sample damage by visually estimating the percentage of seed missing from the head. The observations were carried out for four weeks and ended two days before harvesting.

\section{Conclusions}

Sprouting corn: The average of plants damaged was 5.13 (s.d. 0.55 ) vs. 1.2 (s.d $0.29)$ in the control plot vs. the Helikite plot $(\mathrm{P}<0.0001)$. The percentage of plants damaged in the control plot was $19.1 \%$ vs. $4.2 \%$ in Helikites plot $(\mathrm{P}<0.0001)$. Ripening sunflower: At the beginning of the test, the mean percentage of seed missing from sunflower heads was 0.84 in the Helikite plot and 0.76 in the control plot $(\mathrm{P}=0.914)$. At the end of the last week (two days before harvesting) damage level was 1.16 vs. $13.25(\mathrm{P}<0.0001)$. The damage levels in relation to the distance from the Helikite were 1.05 - 1.63, 0.81, 2.56, 1.40, 11.05, 15.70, 10.58 for $\pm 30 \mathrm{~m}, 60 \mathrm{~m}, 120 \mathrm{~m}, 180 \mathrm{~m}, 240 \mathrm{~m}, 300 \mathrm{~m}$, and $360 \mathrm{~m}$, respectively.

We conclude that Helikites can have a deterrent effect on birds and can protect crops on short time. Further experiments are however necessary to better define the species-specific responses and the efficacy of the Helikites on long term, since habituation usually reduces the efficacy of every scaring device. The incidence of maintenance, in relationship to different weather conditions, and the number of replacing needed in relationship to the different abrasive crops should be evaluated before the use of this scaring device.

\section{REFERENCES}

Conover M., 2002 - Resolving Human - Wildlife Conflicts. The Science of Wildlife Damage Management - Lewis Publisher, New York, 418 pp. 
GorReri L. \& Moscardini G., 1997 - I danni provocati alle colture agrarie dalla fauna selvatica nei Parchi Naturali. Le specie coinvolte, le tipologie di danni e i mezzi per contenerle - Ente Parco Regionale Migliarino San Rossore Massaciuccoli, Pisa, 67 pp.

Santilli F., Azara S., Galardi L., Gorreri L. \& Perfetti A., 2004 - Un nuovo metodo ecologico per la prevenzione dei danni da uccelli alle colture agricole - ARSIA, Firenze, 22 pp.

Seamans T.W., Blackwell B.F. \& Gansowski J.T., 2002 - Evaluation of the Allsopp Helikite ${ }^{\circledR}$ as a bird-scaring device. In: Tiмм R.M. \& SснміDт R.H. (eds). Proceedings 20th Vertebrate Pest Conference - University of California, Davis, pp. 129-134.

\author{
Francesco Santilli ${ }^{1}$, Silvio Azara ${ }^{2}$, Lorenzo Galardi ${ }^{3}$, Luca Gorreri ${ }^{4}$, Antonio \\ PERFETTI ${ }^{4} \&$ Marco BAgLiacca ${ }^{1}$ \\ ${ }^{1}$ Dipartimento di Produzioni Animali. Università di Pisa - Via delle Piagge, 2 - I-56100 Pisa \\ E-mail: perdix@alice.it \\ ${ }^{2}$ Tecnico faunista - Via di Metato - I-56100 Pisa \\ ${ }^{3}$ Agenzia Regionale per lo Sviluppo e l'Innovazione nel Settore Agricolo-forestale, Firenze \\ ${ }^{4}$ Ente Parco Regionale Migliarino, S. Rossore e Massaciuccoli, Pisa
}

\title{
DENSITÀ DI CORVUS CORONE CORNIX E PICA PICA IN DIFFERENTI TIPOLOGIE AMBIENTALI DEL NORD DELLA CALABRIA
}

Abstract - Density of Corvus corone cornix and Pica pica in different environmental typologies of North Calabria.

Problematic bird species are interesting for their remarkable implications mostly in the economic field, and many efforts are made for their management by public administrations. The present study investigated the densities of Hooded Crow, Corvus corone cornix, and Magpie, Pica pica, in eight environments which form the main environmental typologies of the central southern part of the province of Cosenza. The study was conducted counting the nests along linear transects in wintertime. The value of total densities found for both corvid species are, on average, low if compared with the values found in North and Central Italy in the most recent years.

\section{Introduzione}

Cornacchia grigia, Corvus corone cornix, e Gazza, Pica pica, poiché considerate specie problematiche, sono oggetto di attenzione da parte di studiosi e pubbliche amministrazioni. In particolari condizioni di densità, infatti, tali specie possono interferire con alcune attività antropiche. In ambito economico e naturale sono ricorrenti, ad esempio, i danni arrecati alle colture agricole oltre che la predazione di nidi di Passeriformi e Galliformi di interesse venatorio (Gustin, 1999, 2002).

Sebbene finalizzati ad una applicazione gestionale, i risultati ottenuti nel presente lavoro, commissionato dal Servizio Caccia, Pesca, Programmazione e Gestione Faunistica della Provincia di Cosenza, costituiscono le prime conoscen- 